\title{
VSEŽIVLJENJSKO IZOBRAŽEVANJE ALI VSEŽIVLJENJSKO UČENJE?
}

Pre red skoraj stiridesetimi leti je na svetouni Unescovi konferenci v Montrealu Paul Lengrand predstavil nov in edini mogoči pristop $k$ izobraževanju: permanentno izobraževanje. Že takrat je nastajala $v$ razvitem svetu buda zagata med šolskimi sistemi in potrebami družbe ter gospodarstva po znanju. Kljub reformam ju ni bilo mogoče uskladiti, nasprotno, pridobljeno šolsko znanje se je celo čedalje bolj oddaljevalo od dejanskih potreb. Paul Lengrand, dolgoletni direktor pariškega pedagoškega inštituta, je dokazal, da po starem (s predhodnim šolanjem) ni več mogoče pripraviti ljudiza vse življenje, temveč je treba znanje pridobivati use življenje.

Med liudmi ni izjem. Pred to dejstvo je postavljen vsak človek, ne glede na starost, poklic ali socialni status ter druge lastnosti. Potrebe po znanju in sposobnosti ljudi so zaradi velikih sprememb ter naglega razvoja nepredvidljive. Šele ko se pojavijo, ljudje ugotovijo, kaj bi morali znati. Navadno je čas za učenje kratek, ko potrebo po znanju ugotovijo, bi namreč morali že znati. Zato ni dovolj, da bi se zanašali na to, da jih bo "življenje izučilo".

$V$ šestdesetih in sedemdesetih letih so bili $v$ strokouni literaturi razširjeni izrazi "permanentno izobraževanje, teorija permanentnega izobraževanja, razširjena praksa permanentnega izobraževanja itd. «. Problem je nastal pri prevajanju strokounih besedil iz francoščine $v$ angleščino, ker tujka "permanent " $v$ angleščini ni nič pomenila. Angleški avtorji so se čedalje bolj oprijemali novega izraza "vseživljenjsko izobraževanje" (lifelong education). Oba izraza sta bila razširjena $v$ strokovni literaturi $v$ osemdesetih letih in $v$ začetku devetdesetih let, odvisno od tega, $v$ katerem jeziku je bilo besedilo napisano. Pri nas sta se uveljavila oba izraza. Uporabljali smo ju (in tako ju še danes) kot sinonima.

Ker so se v zadnjih letih potrebe po znanju, novih sposobnostih in osebnostnih lastnostih izrazito povečale, se je zlasti načrtovalcem izobraževanja zdelo, da postaja položaj nevzdržen. To je bilo najbolj opazno med

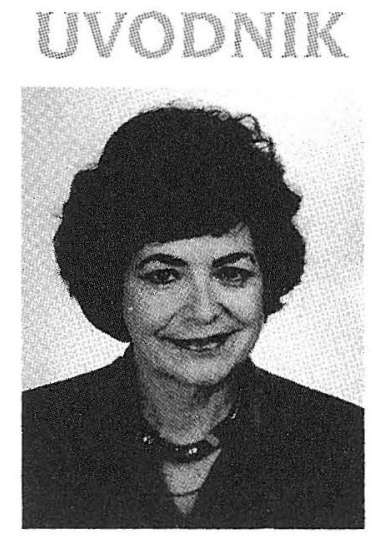

dr. Ana Krajnc politiki, ki bi se morali aktivno odzvati na tako velike potrebe po izobrazbi. Domislili so se čedalje sprejemljivejšega izraza vseživljenjsko učenje, ki pa je neobvezujoč. Toda kaj je potem tako novega v vseživljenjskem učenju, saj se ljudje učijo vse življenje, odkar obstaja človeštvo? Velik razvojni premik je bil, ko je Paul Lengrands sodelavci razglasil, da se morajo ljudje izobraževati use življenje, kar pomeni izčrpno, ciljno, strukturirano in načrtno pridobivanje novega znanja, stališč, vrednot in sposobnosti, odvisno od njihovih življenjskib potreb in hotenj. Učenje na podlagi osebnih izkušenj na današnji razvojni stopnji več ne zadošča. Izobraževanje je posebna, višja oblika učenja, bolj zgoščena in je ne moremo zamenjevati $z$ učenjem, ker bi s tem zanikali velike razvojne spremembe (C. Titmus).

Tudi strokounjaki so se v zadnjih dveh letih zadovoljili z izrazom "vseživljenjsko učenje", čeprav so do sedaj govorili o vseživljenjskem izobraževanju. Knjigo s tem naslovom je leta 1996 izdal nemški avtor Gunter Dohmen. Gre za strogo strokouno besedilo in dejansko obravnava vzgojo in izobraževanje odraslih, in ne učenja ljudi na splošno. Alen Thomas, kanadski avtor raziskuje "naravne oblike izobraževanja «. Zanima ga, kako se usposabljajo ljudje v kulturah brez šol. Ukvarja se predvsem s psihologijo izobraževanja odraslih in uporablja oba izraza, tudi useživljenjsko učenje. Pri nas se nagiba k izrazu "vseživljenjsko učenje "namesto »useživljenjsko izobraževanje "Zoran Jelenc, ki si prizadeva, da bi priznali tudi neformalne oblike izobraževanja odraslib in jih tudi uporabljali. Oblasti, ki se želijo znebiti odgovornosti za znanje ljudi, lahko uporabljajo tudi ohlapnejše izrazje (v tem primeru vseživljenjsko učenje), če s tem dosežejo svoj politični cilj. Stroka svojih osnovnih kategorij (ena izmed njih je tudi permanentno ali vseživljenjsko izobraževanje) ne more prezreti ali jih mimogrede zavreči, ker bi labko s tem porusila celotno strukturo znanstvene discipline. 